\title{
A CASE OF SPINDLE CELL CARCINOMA OF THE UTERINE CERVIX
}

\author{
SI-A Choi, MD1', Mi-Ra Lee, MD1', Min-Jeong Kim, MD', Hye-Ji Jeon, MD', Yun-Sook Kim, MD', \\ Dong-Han Bae, MD', Chang-Jin Kim, MD² \\ Departments of ${ }^{1}$ Obstetrics and Gynecology, ${ }^{2}$ Pathology, Soonchunhyang University Cheonan Hospital, Soonchunhyang University College of Medicine, Cheonan, \\ Korea
}

Spindle cell carcinoma is a rare variant of squamous cell carcinoma characterized histologically by a biphasic pattern with both squamous and spindle cell component. There is controversy in the histogenesis, biologic behavior, optimal treatment and prognostic factor for tumor. Treatment must be similar for squamous cell carcinoma. With a review of literature, we report a case of a 52-yearold female with spindle cell carcinoma in the uterine cervix, which has been managed by total hysterectomy.

Keywords: Spindle cell carcinoma; Uterine cervix; Hysterectomy

방추세포암종은 상피조직과 간엽조직을 가지는 편평세포암종의 아 류로 생각되며, 유육종성 상피암종으로 불리기도 한다[1]. 전체 상기 도와 소화기관에 발생하는 악성종양 중 매우 드문 암종으로 $0.57 \%$ 를 차지하며, 편평상피점막 어느 곳에서도 발생할 수 있다[2]. 1864년 Virchow에 의해 처음 보고된 이래 악성도 및 발생기전에 대한 저자 간 의 이견으로 가성육종, 상피육종, 다형성 상피암종, 육종양 상피암종, 가성 육종 상피암종 등으로 혼용되었으나 최근 상피세포기원으로써 방 추모양을 가지는 세포의 특징으로 방추세포암종으로 기술되고 있다 $[3,4]$.

방추세포암종은 주로 두경부 특히 후두와 인두 등 상기도에 발생하 고 구강, 식도, 여성 생식기, 피부에서의 발생도 보고되고 있으며 드문 종양으로 보고된 예가 적어서 최근까지도 이 종양의 조직형성, 치료, 예후 인자 등에 대한 논란이 많다[5].

저자들은 최근 매우 드물게 자궁경부에 발생한 방추세포암종 1 예를 진단하여 자궁절제술로 치료한 예를 경험하였기에 문헌 고찰과 함께 보고하는 바이다.

\section{증례}

환 자: 전 $O$ 옥, 52 세

산과력: 3-0-2-3, 3회의 질식분만을 하였고, 당뇨나 고혈압 등은 없 었다.

월경력: 14 세에 초경을 시작하여 28일 주기로 규칙적이고 기간은 7일 이었으며, 양은 중등도이었고 월경통은 없었다. 1년 전에 폐경되었으
며, 한번도 자궁경부암 선별검사를 해 본적이 없었다.

주소 및 현병력: 환자는 중국 연변 조선족으로 4년 전 한국인과 재혼 한 상태였으며, 2011년 6월 9일 본원에서 국민건강보험공단에서 시행 한 자궁경부 세포진검사에서 침습이 의심되는 고등급 편평상피내 병변 (high grade squamous intraepithelial lesion with features suspicious for invasion)이 나왔다. 2011년 8월 2일 본원 외래 방문하여 시행한 질 확대경하 자궁경부착공생검에서 공동세포성 비정형 동반한 방추세포 암(spindle cell carcinoma with koilocytosis) 소견을 보였으며(Fig. 1), 인유두종 바이러스 16 번 검출되었다. 질초음파에서 자궁과 난소에 특 이소견 없었으며, 자궁 뒤쪽의 더글라스와에 적은 양의 액체 저류 소견 을 보였고, 10 년 전 중국에서 넣은 자궁내 피임장치가 삽입된 상태였 다. 외래에서 자궁내 피임장치를 제거하였다. 환자는 자궁경부암 병기

Received: 2011.12.2. Revised: 2012.1.19. Accepted: 2012.2.16. Corresponding author: Yun-Sook Kim, MD

Department of Obstetrics and Gynecology, Soonchunhyang University Cheonan Hospital, Soonchunhyang University College of Medicine, 8 Soonchunhyang 2-gil, Dongnam-gu, Cheonan 330-930, Korea Tel: +82-41-570-2150 Fax: +82-41-571-7887

E-mail: drsook@schmc.ac.kr

This is an Open Access article distributed under the terms of the Creative Commons Attribution Non-Commercial License (http://creativecommons.org/licenses/ by-nc/3.0/) which permits unrestricted non-commercial use, distribution, and reproduction in any medium, provided the original work is properly cited.

Copyright (๑) 2012. Korean Society of Obstetrics and Gynecology 
설정을 위한 기본검사를 위해 입원하였다.

과거력: 환자는 외상의 기왕력, 약물 복용력, 음주, 흡연, 면역억제제 복용력, 방사선 치료 등의 과거력 전혀 없었다.

가족력과 수술력: 특이 소견 없었다.

신체검사 소견: 입원 당시 신체 검진에서 혈압 $130 / 80 \mathrm{~mm} \mathrm{Hg}$, 맥박 78 회/분, 호흡수 20 회/분, 체온 $36.8^{\circ} \mathrm{C}$ 이었고 의식은 명료하였다. 흉 부 소견에서 호흡음은 깨끗하였고, 심박동은 규칙적이었으며, 심잡음 은 들리지 않았다.

검사실 검사 소견: 혈액검사에서 혈색소는 $11.9 \mathrm{~g} / \mathrm{dL}$ (범위, 12.0-

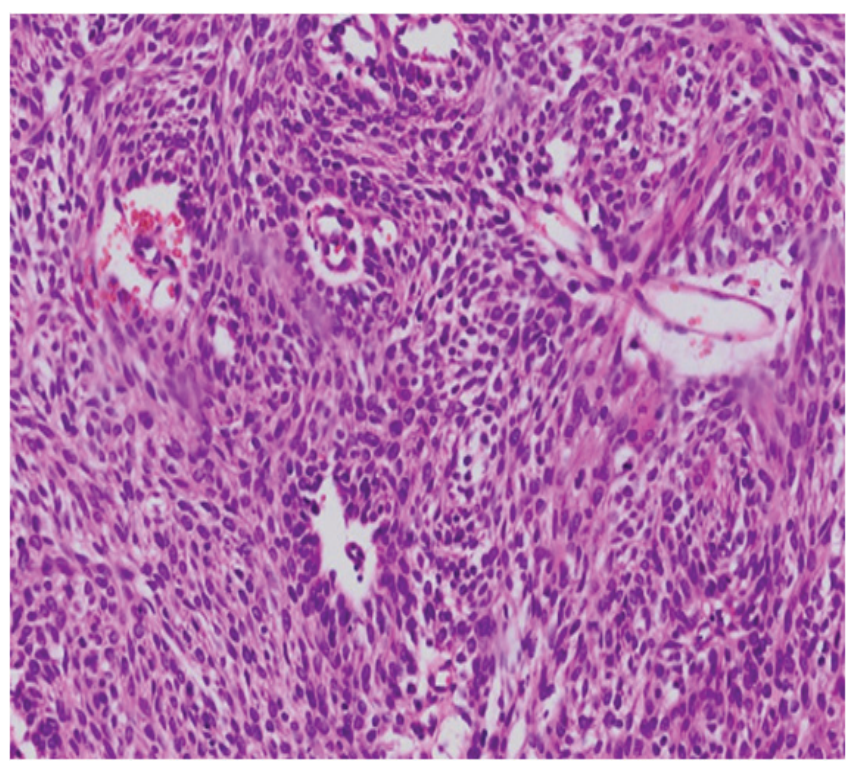

Fig. 1. Punch biopsy reveals carcinoma composed of spindle cells (H\&E, $\times 200$ ).

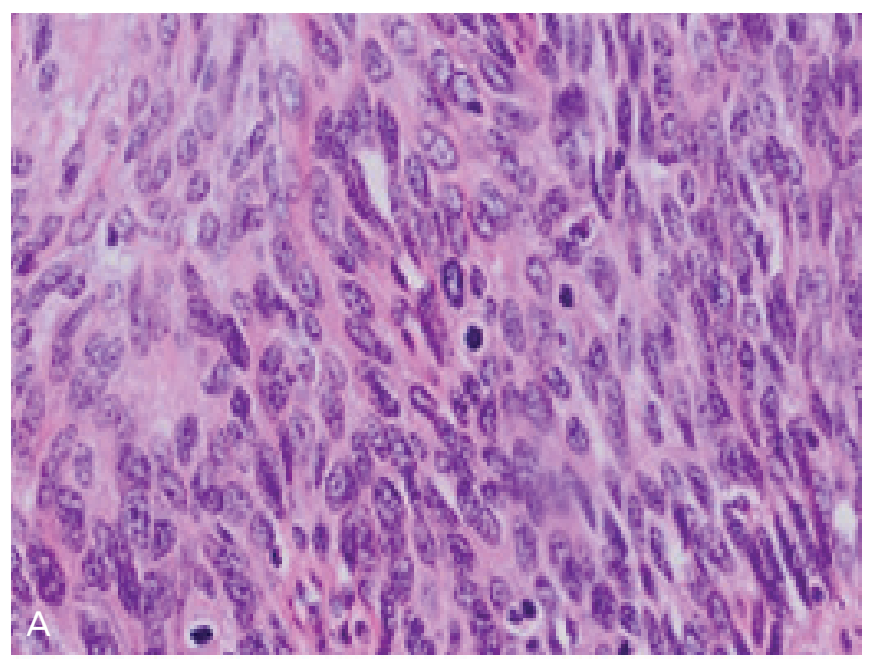

$16.0 \mathrm{~g} / \mathrm{dL}$ )로 정상이었으나, 백혈구 1,740/. $\mathrm{mm}^{3}$ (범위, 4,000-10,000/ $\mathrm{mm}^{3}$ ), 혈소판은 $58,000 / \mathrm{mm}^{3}$ (범위, $130,000-400,000 / \mathrm{mm}^{3}$ )으로 감 소되어 있었다. Prothrombin time은 $15.1 \mathrm{sec}$ (범위, 9.8-12.4 sec), activated partial thromboplastin time은 $55.1 \mathrm{sec}$ (범위, 20.4-36.7 $\mathrm{sec}$ )로 연장되어 있었다. 생화학검사에서 protein $5.9 \mathrm{~g} / \mathrm{dL}$ (범위, 5.8$8.1 \mathrm{~g} / \mathrm{dL}$ ), albumin $3.2 \mathrm{~g} / \mathrm{dL}$ (범위, 3.1-5.2 g/dL)로 정상 소견보였 고, total bilirubin $0.7 \mathrm{mg} / \mathrm{dL}$ (범위, 0.2-1.2 mg/dL)이었고, aspartate aminotransferase $38 \mathrm{IU} / \mathrm{L}$ (범위, 0-40 $\mathrm{U} / \mathrm{L}$ ), alanine aminotransferase $33 \mathrm{U} / \mathrm{L}$ (범위, 0-40 IU/L)로 정상이었다. Alkaline phosphatase, urea nitrogen, creatinine 수치는 정상이었다. B형 간염, C형 간염항원검사, 그리고 요검사에서 이상 소견 없었다. 흉부 X선촬영, 심전도에서 이상 소견 없었다. 골스캔검사에서 특이소견을 보이지 않았다.

복부 초음파 소견: 백혈구와 혈소판이 감소되어 있고, prothrombin time, activated partial thromboplastin time이 연장되어 있어 시행한 복 부 초음파에서 원인 미상의 간경변과 비장 비대 소견 보였다.

자기공명영상 및 양전자방출단층촬영 소견: 자기공명영상에서 자궁경 부에 명확한 종괴 소견 보이지 않았고, 골반 내 림프절 비대 소견 보 이지 않았다. 그 외 비장비대와 간과 췌장의 단순 낭종 소견 보였다. 양전자방출단층촬영에서 자궁경부에는 과대사 병변(hypermetabolic lesion) 보이지 않았으며, 좌측 골반에 전이가 의심되는 림프절 비대소 견 보였다.

치료 및 경과: 환자는 8월 2일에 입원하여 혈소판이 계속 58,000/ $\mathrm{mm}^{3}$ 낮아 혈액 종양내과와 상의 후 비장비대 이외에는 영상과 혈액 검사와 다른 이상이 없어 2011년 8월 19일 자궁경부 원추절제수술 시 행하였으며, 원추절제수술 결과 소량의 방추세포 분화ffocal spindle cell differentiation)를 동반한 깊이 $1 \mathrm{~mm}$, 내자궁경부 절제면에 tumor involvement가 있는 편평세포암, 자궁경부 미세침윤암 la1소견 보였 다. 림프혈관강 침윤은 보이지 않았다. 2011년 8월 24일 개복하여 전

Fig. 2. (A) Cone biopsy of the cervix shows squamous cell carcinoma, focal fascicles of proliferating spindle cell, which considerable mitotic activity, and focal moderate degree of nuclear atypia $(H \& E, \times 400)$. (B) Immunohistochemical finding shows positive reaction for smooth muscle actin (smooth muscle antigen, $\times 400)$. 


\section{KOREAN JOURNAL OF OBSTETRICS \& GYNECOLOGY}

Sl-A Choi, et al. Spindle cell carcinoma of the uterine cervix

자궁절제술과 양측난소난관절제수술 시행하였다. 양전자방출단층촬영 에서 좌측 골반에 전이가 의심되는 림프절 비대소견 보였으나 수술 중 만져지는 커져 있는 림프절 소견 없었고, 병기 la1으로 추가 림프절 절 제는 필요 없을 것으로 사료되어 시행하지 않았다. 최종 병리학적 검 사에서 자궁경부는 중증도의 자궁경부 세포이형성증 소견이었고, 원추 절제 후 잔여 암조직 보이지 않는 선 침윤 동반한 깨끗한 절제면(clear resection margin with glandular involvement) 소견이었다. 그 외 자궁 내막 및 근육층, 양쪽 난소난관에 특이 소견 보이지 않았다. 최종 병기 la1으로 추가 치료 없이 수술 5일째 퇴원했다. 현재 재발의 소견 없이 5 개월째 외래 추적관찰 중이다.

병리학적 소견: 원추절제 결과 소량의 방추세포 분화를 동반한 편평 세포암 보였다. 유사분열 활동성을 가지고 중등도의 비정형화된 핵을 보이는 증식성의 방추세포가 보였으며, 평활근 항원(smooth muscle antigen)에 양성 소견 보였다(Fig. 2).

\section{고 찰}

방추세포암종은 1864년 Virchow에 의해 암육종(carcinosarcoma)으 로 처음 명명되었으나, 현재는 단일세포군(monoclonal)의 상피세포가 중간엽 분화를 하는 것으로 암육종과는 다른 조직생성을 갖는 것으로 알려져 있다. 상기도 및 상부소화관에서 발생하는 악성종양 중 $0.57 \%$ 를 차지하는 아주 드문 종양으로, 대부분 구강 및 후두에서 발견된다 [6]. 아직까지 자궁경부에서 발생한 보고는 없다. 전신적으로는 식도, 피부, 여성생식기관, 갑상샘, 췌장, 유방, 신장, 방광, 항문 등에서 발생 한 예가 보고되어 있다[7].

성별 및 연령분포를 보면 60-70대의 남성에서 호발하며, 외상이나 방사선과 관련되어 발생하며 흡연, 음주, 불결한 구강위생 등과의 연 관성이 보고되었다. 상기 환자의 경우는 52세의 여자환자로 외상, 방 사선 등과의 관련은 없었고, 자궁내 피임장치를 10년 이상 가지고 있 었고, 인유두종 바이러스 16번에 감염되어 있었다. 병리학적으로 국소 적인 상피성 종양세포와 그 주위를 둘러싸고 있는 다형의 방추세포가 특징적인 소견이다. 세사 단백질은 vimentin, desmin이나 cytokeratin, epithelial membrane antigen (EMA), smooth muscle antigen (SMA) 등의 상피표식자들에 대한 면역학적 염색이 진성 육종(true sarcoma) 과 감별 진단하는 데 이용된다[7]. 상기 환자도 SMA에 양성 소견이어 서 진성육종과 감별이 되었다.

방추세포암종의 발생가설은 이전부터 많은 논란이 있어 왔다. 처음 으로 이 암을 명명한 Virchow는 상피세포와 간엽세포가 각각 따로따로 악성변화를 갖는 충돌이론을 제시했으나, Lane [8]은 방추세포는 인근 편평세포암종에 대한 이차적인 반응현상으로 자발적 전이능력은 결핍 되어 있다고 주장하였다. 현재 이 암종의 발생에 대해 가장 일반적으로 받이들여지고 있는 가설은 단일세포군의 상피세포가 편평세포와 방추 세포로 각각 분화된다는 것이다. 방추세포암종은 hematoxylin \& eosin $(\mathrm{H} \& \mathrm{E})$ 염색만으로는 감별진단이 어려워, 평활근 항원(SMA) 등과 같은
면역조직학적 방법으로 진단해야 한다. 절제생검 조직이 적을 경우 상 피성분을 관찰할 수 없어 육종으로 오진할 수 있다. 5 개 이상/10 고배 율 시야의 유사분열 활동성을 가지고 중등도의 비정형화된 핵을 보이 는 증식성의 방추세포를 관찰할 수 있으면 방추세포암으로 진단할 수 있다. 상기 환자의 경우 H\&E 염색에 의해 증식하는 방추세포가 잘 확 인되었고, 추가 염색인 SMA에도 양성 소견 보여 최종 진단되었다. 조 직검사에서 감별진단으로 섬유육종, 평활근육종, 골육종, 악성 섬유성 조직구증, 악성 흑색종 등이 있다. 방사선학적으로 편평상피암종은 골 파괴를 잘 일으키는 반면 대부분의 육종, 조직구증 및 림프종은 골 재 형성(remodeling)을 시키므로 영상에서 골파괴 소견이 보이면 반드시 의심을 해 보아야 한다[9].

치료는 편평세포암과 유사하다. 수술로서 종양을 절제하는 것이며 수술 후 방사선 치료를 병행하기도 하지만, 방사선 치료의 시행기준에 대해서는 정해진 것이 없다[10]. 본 증례의 경우 자궁경부암 최종 병기 la1으로 전자궁절제술 후 추가 치료 없이 재발의 소견 없이 5개월째 외 래 추적관찰 중이다. 방추세포암종은 발병률이 낮고, 특히 자궁경부에 발생한 증례 보고가 없어 예후를 정확히 예측하기 힘들다. 앞으로 자궁 경부 방추세포암종의 임상양상, 예후 및 방사선의 추가 치료효과에 대 한 좀 더 많은 연구가 필요할 것으로 생각된다. 저자들은 최근 자궁경 부에서 매우 발병률이 낮은 방추세포암종을 진단하여 수술로 치료한 예를 경험하였기에 상기 증례를 간단한 문헌 고찰과 함께 보고하는 바 이다.

\section{References}

1. Kim BS, Park JH, Park YK, Kim KS. A case of spindle cell carcinoma accompanied by inverted papilloma. Korean J Otolaryngol-Head Neck Surg 2003;46:520-3.

2. Ferlito A. Histological classification of larynx and hypopharynx cancers and their clinical implications. Pathologic aspects of 2052 malignant neoplasms diagnosed at the ORL Department of Padua University from 1966 to 1976. Acta Otolaryngol Suppl 1976;342:1-88.

3. Randall G, Alonso WA, Ogura JH. Spindle cell carcinoma (pseudosarcoma) of the larynx. Arch Otolaryngol 1975;101:63-6.

4. Olsen KD, Lewis JE, Suman VJ. Spindle cell carcinoma of the larynx and hypopharynx. Otolaryngol Head Neck Surg 1997;116:47-52.

5. Recher G. Spindle cell squamous carcinoma of the larynx. Clinico-pathological study of seven cases. J Laryngol Otol 1985;99:871-9.

6. Ballo MT, Garden AS, El-Naggar AK, Gillenwater AM, Morrison WH, Goepfert $\mathrm{H}$, et al. Radiation therapy for early stage (T1T2) sarcomatoid carcinoma of true vocal cords: outcomes and 


\section{KOREAN JOURNAL OF OBSTETRICS \& GYNECOLOGY}

KJOG Vol. 55, No. 4, 2012

patterns of failure. Laryngoscope 1998;108:760-3.

7. Kim HY, Kim HJ, Choi G, Choi JO. A case of sarcomatoid carcinoma of nasal cavity. Korean J Otolaryngol-Head Neck Surg 1996;39:1705-9.

8. Lane N. Pseudosarcoma (polypoid sarcoma-like masses) associated with squamous-cell carcinoma of the mouth, fauces, and larynx; report of ten cases. Cancer 1957;10:19-41.
9. Minami SB, Shinden S, Yamashita T. Spindle cell carcinoma of the palatine tonsil: report of a diagnostic pitfall and literature review. Am J Otolaryngol 2008;29:123-5.

10. Thompson LD, Wieneke JA, Miettinen M, Heffner DK. Spindle cell (sarcomatoid) carcinomas of the larynx: a clinicopathologic study of 187 cases. Am J Surg Pathol 2002;26:153-70.

\section{자궁경부에 발생한 방추세포암종 1 예}

순천향대학교 의과대학 ${ }^{1}$ 산부인과학교실, ${ }^{2}$ 병리학교실

최슬아', 이미라', 김민정', 전혜지, 김윤숙, 배동한', 김창진

방추세포암종은 조직학적으로 편평세포와 방추세포성분을 모두 가지고 있는 매우 드문 종양이다. 보고가 적어 최근까지도 종양의 조직 형성, 치료, 예후에 대한 논란이 많다. 치료는 편평세포와 유사하다. 최근 저자들은 52세 여성에서 자궁경부에 발생한 방추세포암종을 진 단하여 전자궁절제술로 치료한 드문 예를 경험하여 문헌 고찰과 함께 보고하는 바이다.

중심단어: 방추세포암종, 자궁경부, 자궁절제술 